\title{
A research on seroprevalence of Neospora caninum in cattle
}

\author{
H. Ahmet ÇELİK ${ }^{1}$, Esma KOZAN², Mustafa ESER ${ }^{2}$, Oktay YILMAZ ${ }^{1}$, M. Kürşad BİRDANE ${ }^{1}$, \\ H. Ŏguz SARIMEHMETOĞLU
}

\begin{abstract}
${ }^{1}$ Afyon Kocatepe University Faculty of Veterinary Medicine Department of Obstetrics and Gynecology, Afyonkarahisar; ${ }^{2}$ Afyon Kocatepe University Faculty of Veterinary Medicine Department of Parasitology, Afyonkarahisar; ${ }^{3}$ Ankara University Faculty of Veterinary Medicine Department of Parasitology, Ankara, Turkey.
\end{abstract}

\begin{abstract}
Summary: This study was carried out in order to determine the seroprevalence of Neospora caninum in cattle in the region of Afyonkarahisar in western Turkey. For this purpose, blood samples were collected from 109 cattle younger than 2-year-old and 376 cattle older than 2-year-old and sera were obtained from these samples. Sera were examined for antibodies against N.caninum using a commercial competitive ELISA (cELISA) kit. Accordingly, seroprevalence of N.caninum in Afyonkarahisar was found to be 21.03 $\%$. Furthermore, no significant relationship was found between age and seropositivity, however, it was observed that 32 of 62 aborting cows $(51.6 \%)$ showed seropositivity. Moreover, the differences between aborting and nonaborting seropositive cattle was significant statistically $(\mathrm{p}<0.001)$. In conclusion, the antibodies of $N$. caninum was determined in cattle of Afyonkarahisar province and it is suggested that N.caninum should be taken into consideration in abort cases of cattle, however, the isolation of N.caninum from aborted cow foetus has to be performed to confirm the diagnosis.
\end{abstract}

Key words: Afyonkarahisar, cattle, Neospora caninum, seroprevalence.

\section{Sığırlarda Neospora caninum seroprevalansı üzerine bir araştırma}

Özet: Bu çalışma Türkiye'nin batısında Afyonkarahisar yöresi sı̆̆ırlarında Neospora caninum seroprevalansını belirlemek amacıyla yapılmıştır. Bu amaçla çalışmada 2 yaşından küçük 109, 2 yaşından büyük 376 sığırdan kan örnekleri alınmış ve serumları çıkarılmıştır. Serumlar ticari kompetatif ELISA (cELISA) kiti kullanılarak N.caninum'a karşı oluşan antikorlar yönünden incelenmiştir. Buna göre Afyonkarahisar'da N.caninum seroprevalansı \% 21.03 olarak tespit edilmiştir. Ayrıca yaş ile seropozitiflik arasında bir ilişki belirlenmemiş ancak geçmişinde abort hikayesi bulunan 62 sı̆̆ırın 32'sinin (\% 51.6) seropozitif olduğu gözlenmiştir. Abort yapan ve yapmayan seropozitif sığırlar arasındaki farklılık istatistiksel olarak da anlamlı bulunmuştur (p <0.001). Sonuç olarak bu çalışma ile Afyonkarahisar yöresi sı̆̆ırlarında N.caninum antikorları tespit edilmiş, abort vakalarında hastalığın gözardı edilmemesi gerektiği ancak kesin tanı için fötustan etken izolasyonuna gidilmesinin uygun olacağı gözlenmiştir.

Anahtar sözcükler: Afyonkarahisar, Neospora caninum, seroprevalans, sığır.

\section{Introduction}

Cattle, which can be raised in almost all parts of the world, excluding the North and South poles, are used by mankind not only for the production of meat and milk as food, but also for their draught power and dung. Of the global milk production $86.3-89.5 \%$ and of the global meat production nearly $25 \%$ is obtained from cattle alone. Cattle are also of great economic significance in Turkey and according to data pertaining to the year 2011, the cattle population of the country is 11.369 .800 (7). Despite the relatively high population of cattle in Turkey, it is evident that the maximum yield is not able to be obtained from these animals. One of the underlying reasons of low yields is parasitic diseases.

Neospora caninum is the primary protozoan cause of abortion in both beef and dairy cattle across the world $(4,10,27)$. In cattle, it was first isolated from an aborted foetus (11).
Neosporosis is common across the world. It is estimated that approximately $42 \%$ of the global cattle population suffers from abortion due to neosporosis. The seroprevalence of the disease differs among countries and regions, and also varies with the serological tests used for diagnosis (15).

Serological tests aid as important tools for the determination of the epidemiology of bovine neosporosis. Based on the results of serological tests, it is indicated that the most effective route of transmission is vertical transmission (5).

The serological tests most commonly used for the serological diagnosis of Neospora caninum are ELISA (14) and IFAT $(12,14)$. ELISA is particularly advantageous for the monitoring of large-scale herds (1).

No information is available on the epidemiology of N.caninum in cattle raised in the vicinity of Afyonkarahisar province. For this reason, the present 
study was undertaken with an aim to determine the seroprevalence of N.caninum in the vicinity of Afyonkarahisar province in western Turkey.

\section{Materials and Method}

The present study was conducted from March 2009 to March 2011 in dairy cattle farms with abortion problems, which were located in the Bolvadin, Çay, Sultandağı, İhsaniye, Çobanlar and İscehisar districts and the centre of Afyonkarahisar province. A hundred and nine animals younger than two years of age and 376 cattle older than two years of age were used in the study.

Blood samples were taken from the vena jugularis of the animals into syringes and were stored at $-20^{\circ} \mathrm{C}$ until the extraction and analysis of sera.

The presence of antibodies against Neospora caninum in bovine serum samples was investigated using a commercial cELISA kit (VMRD Inc. Veterinary Medical Research and Development, Pullman, WA, USA). The test was performed according to the instructions of the manufacturer and the results were assessed at a wavelength of $620 \mathrm{~nm}$ using an ELISA reader (MWGt Lambda Scan 200, Bio-Tek Instruments, VT, USA). The chi-square test available with the SPSS software package was used for the statistical analyses of the results.

\section{Results}

At the end of the study, it was determined that, out of the 485 cattle $102(21.03 \%)$ were positive for antibodies against N.caninum. The distribution of seropositivity according to the study locations is shown in Table 1, the distribution according to the age groups of the animals is shown in Table 2, and the distribution according to the animals that did and did not present with abortion is shown in Table 3 .

Tablo 1. Seropozitifliğin çalışma alanlarına göre dağılımı. Table 1. Distribution of seropositivity in Afyonkarahisar Province from which samples were collected.

\begin{tabular}{cccc}
\hline Study area & $\begin{array}{c}\text { Number of the } \\
\text { examined cattle }\end{array}$ & $\begin{array}{c}\text { Number of the } \\
\text { positive cattle }\end{array}$ & $\begin{array}{c}\text { Seropositivity } \\
(\%)\end{array}$ \\
\hline Bolvadin & 102 & 27 & 26.5 \\
Çay & 88 & 24 & 27.3 \\
Sultandağ1 & 41 & 3 & 7.3 \\
İhsaniye & 48 & 11 & 22.9 \\
Çobanlar & 80 & 11 & 13.8 \\
İscehisar & 37 & 9 & 24.3 \\
Merkez & 89 & 17 & 19.1 \\
\hline
\end{tabular}

Tablo 2. Seropozitifliğin Yaş Gruplarına Göre Dağılımı. Table 2. Distribution of seropositivity in different age groups.

\begin{tabular}{cccc}
\hline Age & $\begin{array}{c}\text { Number of the } \\
\text { examined cattle }\end{array}$ & $\begin{array}{c}\text { Number of the } \\
\text { positive cattle }\end{array}$ & $\begin{array}{c}\text { Seropositivity* } \\
(\%)\end{array}$ \\
\hline$<2$ & 109 & 29 & 26.6 \\
$>2$ & 376 & 73 & 19.4 \\
\hline
\end{tabular}

* Difference of age groups was not significant $(\mathrm{p}>0.05)$.
Tablo 3. Seropozitifliğin Abort Yapan ve Yapmayan Siğırlara Göre Dağılımı.

Table 3. Distribution of seropositivity of aborting and nonaborting cattle.

\begin{tabular}{lccc}
\hline & $\begin{array}{c}\text { Number of the } \\
\text { examined } \\
\text { cattle }\end{array}$ & $\begin{array}{c}\text { Number of } \\
\text { the positive } \\
\text { cattle }\end{array}$ & $\begin{array}{c}\text { Seropositivity } \\
*(\%)\end{array}$ \\
\hline $\begin{array}{l}\text { Aborting cattle } \\
\begin{array}{l}\text { Non-aborting } \\
\text { cattle }\end{array}\end{array}$ & 62 & 32 & 51.6 \\
\hline
\end{tabular}

* Difference of aborting and non-aborting cattle was found to be statistically significant $(\mathrm{p}<0.001)$

\section{Discussion and Conclusion}

Bovine neosporosis, which emerged for the first time in 1987 in a cattle farm in Mexico in the form of an epidemic of abortion, is considered as a major reproductive problem of cattle across the globe. The disease is reported to be particularly prevalent in North America and is noted to have economic significance in all 6 continents due to the abortions and production losses it causes (6). According to various serological studies, seropositivity for neosporosis has been reported as $12.5 \%$ in Wales and England (13); $14.09 \%$ in Brazil (17); $36.8 \%$ in the dairy cattle and $17.9 \%$ in the beef cattle population of Spain (24); $10.5 \%$ in Iran (22); in Vietnam 5.5\% (18); 34.6\% in Romania (16) and in South Australia $2.5 \%$ of the beef cattle and $3.8 \%$ of the dairy cattle population (21). In a retrospective study conducted in cattle raised in the Central Anatolia Region of Turkey (8), seropositivity was found to range between 5.10$32.72 \%$, whilst in another study conducted in different provinces of the same region seropositivity was determined as $13.96 \%$ (29). Furthermore, seropositivity has been reported as $2 \%$ in Kars province (2); $15 \%$ in Elazı $\breve{g}$ province, $4 \%$ in Malatya province, $4.86 \%$ in Muş province and $4.69 \%$ in Bingöl province (3); $9.2 \%$ in Sakarya province (23); $8.02 \%$ in Tekirdağ and Kurklareli provinces (9); 7.5\% in Şanlıurfa province (26); and 7\% in Kayseri province (19). In the present study, of the cattle population investigated in Afyonkarahisar province, $21.03 \%$ were determined to have antibodies against N.caninum in their serum and this rate was ascertained to be in parallel with the results of other studies conducted in Turkey and different parts of the world.

In previous research conducted on the epidemiology of neosporosis, different opinions have been expressed on the correlation between age and seroprevalence. While some researchers $(20,25,28)$ have reported that seropositivity increases with age, some other researchers $(13,24)$ have indicated that no correlation exists between seropositivity and age. In the present study, it was demonstrated that the difference observed between the seroprevalence of animals younger than two years of age $(26.6 \%)$ and animals older than two years of age (19\%) was statistically insignificant $(\mathrm{p}>0.05)$. It was considered 
that this difference may have arisen from differences in the housing and management of the animals or from animals included into the herd from other provinces.

In cattle, neosporosis leads to several economic losses, of which the primary is abortion. It is estimated that approximately $42 \%$ of the global cattle population suffers from abortion due to neosporosis (15). It has been reported that the risk of abortion is $3-7.4 \%$ greater in seropositive animals, in comparison to seronegative animals $(13,28,30)$. Similarly, in the present study, it was determined that out of the 62 cattle with a history of abortion, $32(51.6 \%)$ presented with antibodies against N.caninum in their blood serum, and this finding was found to be statistically significant $(\mathrm{p}<0.001)$. The findings obtained in the present study are in support of the findings of previously conducted studies, yet, in order to confirm the underlying reason of abortion, it is required that the infectious agent be isolated from the aborted foetus.

In conclusion, the present study reports for the first time the seroprevalence of N.caninum in cattle raised in the vicinity of Afyonkarahisar province as $21.03 \%$. It was concluded that age had no effect on seropositivity, that the possibility of neosporosis should be taken into consideration in animals which abort, and that definitive diagnosis requires the isolation of the causative agent from aborted foetuses.

\section{Acknowledgements}

This study was supported by Scientific Research Projects Coordination Unit of Afyon Kocatepe University. Project number: 09.VF.03.

\section{References}

1. Adkinson R, Harper PAW, Reichel MP, Ellis JT (2000): Progress in the Serodiagnosis of Neospora caninum Infections of cattle. Parasitol Today, 16, 110-114.

2. Akça A, Gökçe H (2003): Kars yöresi yerli ve kültür ırkı ithal sığırlarında Neospora caninum'un seroprevalanst. XIII. Ulusal Parazitoloji Kongresi, Konya.

3. Aktaş M, Şaki CE, Altay K, Şimşek S, Ütük AE, Köroğlu E, Dumanlı N (2005): Doğu Anadolu Bölgesinin bazı illerinde bulunan slğırlarda Neospora caninum'un araşttrllmasl. Türkiye Parazitol Derg, 29, 22-25.

4. Anderson ML, Blanchard PC, Barr BC, Subey JP, Hoffman RL, Conrad PA (1991): Neospora-like protozoan infection as a major cause of abortion in California dairy cattle. J Am Vet Med Assoc, 198, 241244.

5. Anderson ML, Reynolds JP, Rowe JD, Sverlow KW, Packham AE, Barr BC, Conrad PA (1997): Evidence of vertical transmission of Neospora sp. infection in dairy cattle. J Am Vet Med Assoc, 210, 1169-1172.

6. Anderson ML, Andrianarivo AG, Conrad PA (2000): Neosporosis in cattle. Anim Reprod Sci, 60-61, 417-431.

7. Anonymous (2011): Türkiye İstatistik Ylllğg 2011. Türkiye İstatistik Kurumu Matbaası, Ankara.
8. Bıyıkoğlu G, Aksoy E, Bozkır M, Küçükayan U, Ertürk A (2001). İ̧ Anadolu Bölgesi siğırlarında Neospora caninum'un varlığının araştırılması. 12. Ulusal Parazitoloji Kongresi, Elazığ.

9. Biyıkoğlu G, Öncel T, Bağcı Ö (2003): Trakya sığırlarında Neospora caninum'un seroprevalansi. XIII. Ulusal Parazitoloji Kongresi. Eylül, 8-12, Konya- Türkiye.

10. Bjerkas I, Mohn SF, Presthus J (1984): Unidentified cystforming sporozoan causing encephalomyelitis and myositis in dogs. Z Parasitenkd, 70, 271-274.

11. Conrad PA, Barr BC, Sverlow KW, Anderson ML, Daft B, Kinde H, Dubey JP, Munson L, Ardans A (1993): In vitro isolation and characterization of a Neospora sp. from aborted bovine foetuses. Parasitology, 106, 239-249.

12. Conrad PA, Sverlow K, Anderson M, Rowe J, BonDurant R, Tuter G, Breitmeyer R, Palmer C, Thurmond M, Ardans A, Dubey JP, Duhamel G, Barr B (1993): Detection of serum antibody responses in cattle with natura lor experimental Neospora infections. J Vet Diagn Invest, 5, 572-578.

13. Davison HC, Otter A, Trees AJ (1999): Significance of Neospora caninum in British dairy cattle determined by estimation of seroprevalence in normally calving cattle and aborting cattle. Int J Parasitol, 29, 1189-1194.

14. Dubey JP, Lindsay DS, Adams DS, Gay JM, Baszler TV, Blagburn BL, Thulliez P (1996): Serologic responses of cattle and other animals infected with Neospora caninum. Am J Vet Res, 57, 329-336.

15. Dubey JP (2003): Review of Neospora caninum and neosporosis in animals. The Korean J Parasitol, 41, 1-16.

16. Gavrea RR, Iovu A, Losson B, Cozma V (2011): Seroprevalence of Neospora caninum in dairy cattle from north-west and centre of Romania. Parasite, 18, 349-351.

17. Gondim LFP, Sartor IF, Hasegawa M, Yamane I (1999): Seroprevalence of Neospora caninum in dairy cattle in Bahia, Brazil. Vet Parasitol, 86, 71-75.

18. Huong LTT, Ljungstro BL, Uggla A, Björkman C (1998): Prevalence of antibodies to Neospora caninum and Toxoplasma gondii in cattle and water buffaloes in southern Vietnam. Vet Parasitol, 75, 53-57.

19. İça A, Yıldırım A, Düzlü Ö, İnci A (2006): Kayseri Yöresinde siğırlarda Neospora caninum'un seroprevalansı. Türkiye Parazitol Derg, 30, 92-94.

20. Jensen AM, Björkman C, Kjelsen AM, Wedderkopp A, Willadsen C, Uggla A, Lind P (1999): Associations of Neospora caninum seropositivity with gestation number and pregnancy outcome in Danish dairy herds. Prev Vet Med, 40, 151-163.

21. Nasir A, Lanyon SR, Schares G, Anderson ML, Reichel MP (2012): Sero-prevalence of Neospora caninum and Besnoitia besnoiti in South Australian beef and dairy cattle. Vet Parasitol, 186, 480-485.

22. Nematollahi A, Jaafari R, Moghaddam G (2011): Seroprevalence of Neospora caninum Infection in Dairy Cattle in Tabriz, Northwest Iran. Iran J Parasitol, 6, 95-98.

23. Öncel T, Bıyıkoğlu G (2003): Sakarya yöresi süt siğırlarında Neosporosis caninum. Uludag Univ J Fac Vet Med, 22, 87-89.

24. Quintanilla-Gozalo A, Pereira-Bueno J, Tabares E, Innes EA, GonzaÂ lez-Paniello R, Ortega-Mora LM 
(1999): Seroprevalence of Neospora caninum infection in dairy and beef cattle in Spain. Int J Parasitol, 29, 1201-1208.

25. Sanderson MW, Gay JM, Baszler TV (2000): Neospora caninum seroprevalence and associated risk factors in beef cattle in the Northwestern United States. Vet Parasitol, 90, $15-24$.

26. Sevgili M, Atlaş MG, Keskin O (2005): Seroprevalence of Neospora caninum in cattle in the province of Şanlurfa. Turk J Vet Anim Sci, 29, 127-130.

27. Thurmond MC, Anderson ML, Blanchard PC (1995): Secular and seasonal trends of Neospora abortion in California dairy cows. J Parasitol, 81, 364-367.

28. Thurmond MC, Hietala SK (1997): Effect of congenitally acquired Neospora caninum infection of abortion and subsequent abortions in dairy cattle. Am J Vet Res, 58, 1381-1385.
29. Vural G, Aksoy E, Bozkir M, Kuçukayan U, Erturk A (2006): Seroprevalence of Neosporacaninum in dairy cattle herds in Central Anatolia, Turkey. Vet Arhiv, 76, 343-349.

30. Wouda W, Moen AR, Schukken YH (1998): Abortion risk in progeny of cows after a Neospora caninum epidemic. Theriogenology, 82, 1311-1316.

Geliş tarihi: 06.11.2012 / Kabul tarihi: 21.01.2013

\section{Address for correspondence:}

Assoc. Prof. Dr. Esma Kozan

Afyon Kocatepe University,

Faculty of Veterinary Medicine,

Department of Parasitology,

03200, Afyonkarahisar, TURKEY. 